Atıf için / For Citation: Ş.R. Yayla, N. Şenol, "Tarımda Kullanılan Bazı Mikrobiyal Gübrelerin Eisenia foetida Deri Dokusu Üzerinde Etkisinin Histolojik Açıdan Değerlendirilmesi”, Süleyman Demirel Üniversitesi Fen Edebiyat Fakültesi Fen Dergisi, 15(2), 213-223, 2020.

\title{
Tarımda Kullanılan Bazı Mikrobiyal Gübrelerin Eisenia foetida Deri Dokusu Üzerinde Etkisinin Histolojik Açıdan Değerlendirilmesi
}

\author{
Şeyma Rukiye YAYLA ${ }^{1}$, Nurgül ŞENOL ${ }^{* 2}$ \\ ${ }^{I}$ Süleyman Demirel Üniversitesi, Fen Bilimleri Enstitüsü, Biyomühendislik Bölümü, 32200, Isparta, \\ Türkiye \\ ${ }^{2}$ Süleyman Demirel Üniversitesi, Sağllk Bilimleri Fakültesi, Beslenme ve Diyetetik Bölümü, 32200, \\ Isparta, Türkiye \\ *yazışılan yazar e-posta: nurgulsenol@sdu.edu.tr
}

(Alınış / Received: 03.03.2020, Kabul / Accepted: 08.10.2020, Yayımlanma / Published: 29.11.2020)

Özet: Bu çalışmada son yıllarda kimyasal gübrelerin yol açtığı çevresel zararlardan dolayı alternatif olarak üretilen mikrobiyal gübrelerin Eisenia foetida türü toprak solucanlarının deri dokusu üzerine etkisinin histolojik açıdan değerlendirilmesi amaçlanmıştır. Bu amaçla Eisenia foetida türlerinden oluşan 3 deney ve 1 kontrol grubu oluşturuldu. Tarımda şu anda kullanılmakta olan 3 farklı mikrobiyal gübre formülasyonu ile Eisenia foetida türü solucanlara 30 gün boyunca sıvı mikrobiyal gübre Biomarket (BM) şirketinden temin edilerek (BM Coton Plus, BM Megaflu, BM Rootpan) uygulaması yapıldı. Denemenin ardından Eisenia foetida toprak solucanlarının vücut orta bölümünden deri dokuları alınıp, histolojik doku takibi uyguland. Kontrol grubuna ait preparatların histolojik incelemesinde derinin epidermis ve dermis olmak üzere tabakalanma gösterdiği saptandı. BM Coton Plus, BM Megaflu, BM Root Pan gruplarında kontrol grubuna benzer histolojik gözlemler yapıldı. Sonuç olarak sıvı mikrobiyal gübre uygulama yapılmasının Eisenia foetida türü toprak solucanlarının deri dokusunda herhangi bir olumsuzluk oluşturmadığı histolojik açıdan tespit edildi.

Anahtar kelimeler: Mikrobiyal gübre, Eisenia foetida, Deri, Histoloji

\section{Histological Evaluation of the Effects of Some Microbial Fertilizers Used in Agriculture on the Skin Tissue of Eisenia foetida}

\begin{abstract}
In this study, it was aimed to evaluate the effect of microbial fertilizers produced as an alternative due to environmental damages caused by chemical fertilizers on the skin tissue of Eisenia foetida type earthworm. For his purpose, 3 experiments and 1 control groups were created. Liquid microbial fertilizer (BM Coton Plus, BM Megaflu, BM Rootpan) was applied to earthworms Eisenia foetida for 30 days with 3 different microbial fertilizer formulations currently used in agriculture. After the trial, skin tissues were taken from the middle body of Eisenia foetida and histological tissue follow-up procedure was performed. The histological examination of the preparations belonging to the control group revealed that the skin showed stratification, including epidermis and dermis. Histological observations in BM Coton Plus, BM Megaflu and BM Rootpan groups were similar to control group. As a result, it was determined histologically that the application of liquid microbial fertilizer did not cause any negative effects on the skin tissue of Eisenia foetida.
\end{abstract}

Key words: Microbial fertilizer, Eisenia foetida, Skin, Histology 


\section{Giriş}

Dünya nüfusunun artması ile birlikte gıdaya olan talep artmıştır. Tarım arazilerinin azalması, ormanların yok edilmesi ve kısa zamanda daha çok ürün isteği nedeniyle tarımda gübre kullanımı ciddi şekilde artmıştır [1]. Kimyasal gübre ve zirai ilaç kullanımının getirdiği çevresel kirlilik insan sağlığını da tehdit etmektedir. Bu nedenle çevreye dost doğal yolla bitkilerin gelişimini düzenleyecek yeni yollar aranmaktadır. Son zamanlarda zirai ilaç ve kimyasal gübreye alternatif gösterilen yöntem organik gübreleme olmuş bunun için en iyi yol ise mikrobiyal destekleme olarak öne sürülmüştür $[2,3,4]$.

Toprakta bitki köklerinin yakın bölgelerinde mikroorganizma populasyonunun en yoğun olduğu bölge 'rizosfer' bölgesi olarak bilinmektedir. Rizosfer bölgesinde bitki köklerinin gramı başına yaklaşık bin mikrobiyal hücre ve bitkinin daha verimli hale gelmesini sağlayan yaklaşık otuz bin prokaryotik tür bulunabilmektedir. $\mathrm{Bu}$ topluluk mikrobiyom olarak bilinir ve bitki köklerinden daha büyüktür. Mikrobiyom topluluğu etkileşime geçtiği bitkinin sağlıklı şekilde büyümesine yardımcı olur; toprakta bulunan organik maddeyi ayrıştırarak bitkinin daha fazla yararlanmasına olanak sağlar, böylece besin kazanımını da artırır. Sağlıklı şekilde büyüyen bitkinin daha çok kılcal kök atmasına olanak sağlayarak su emme kapasitesini arttırır ve bitkilerin patojenlere karşı daha dirençli olmasını sağlar [5]. Rizosfer tabakasında bulunup bitki gelişimini bu şekilde teşvik eden mikroorganizmalara 'bitki büyümesini teşvik eden rizobakteriler (PGPR) adı verilir. PGPR'ler bitkiler üzerinde doğrudan ve dolaylı olmak üzere iki etkiye sahiptir. Bitki büyümesini teşvik etmeleri doğrudan etkileri, salgıladıkları primer ve sekonder metabolitler sayesinde bitkileri fitopatojenlere karşı korumaları ise dolaylı etkileri olarak bilinmektedir. PGPR'ler azot fiksasyonu, fosfor ve potasyum alımı, antibiyotik, enzim ve hormon üretimi gibi birçok konuda görev yapmaktadırlar. PGPR; Azotobakter, Bacillus, Azospirillum, Pseudomonas ve birçok alt türü içinde barındırmaktadır [6].

Bitki büyümesini teşvik eden bakteriler (PGPB), bitki dokularına kolonize olarak onların içlerinde mutualistik şekilde yaşamlarını sürdürebilmektedirler. PGPB türlerinden Bacillus spp'nin alt türü olan Bacillus megaterium topraklarda yaygın şekilde bulunup birçok bitkinin mikrobiyom üyesidir. Köklerini kolonize olduğu bitkinin bitki büyümesini teşvik eder ve antifitopatojen aktivitesi için birçok biyoaktif maddenin üretilmesine olanak sağlar. Bacillus türleri yüksek spor oluşturabilme kabiliyetleri sayesinde stres koşullarına dayanıklıdırlar [7]. B. megaterium doğada bulunan fosfor bileşiklerinin çözümlenmesinde önemli rol oynamaktadır. Ayrıca sitrik, laktik ve propiyonik asit gibi organik asitlerin üretiminde rol almaktadır [8].

Mikroorganizmaların birçoğu rizosfer bölgesi olarak tanımlanan kısımda yaşar. $\mathrm{Bu}$ mikrorganizmalar arasında Pseudomonas türleri de bulunmaktadır. Pseudomonas fluorescens türleri üzerinde yapılan çalışma göstermiştir ki bu türe ait suşlar azot bağlayıcılar, siderofor, oksin, giberellin ve sitokininler gibi bitki büyüme sağlayıcı hormonlar üretebilmektedir. Hızlı ve rekabete dayanıklı kolonileşmeleri sayesinde bu tür diğer patojenlerle de rekabete girmektedirler. Patojenlere karşı etkili olmalarının bir diğer sebebi de hidrojen siyanür, antibiyotik ve siderofor salgılamalarıdır [9].

$P$. agglomerans türünün suşları elma ve armut yanıklığı tedavisinde biyokontrol ajanı olarak kullanılmaktadır. Yine elma sapından elde edilen bir suşu elma ve armut yapraklarında denenmiş ve yaprakların patojenlere karşı koruduğu bildirilmiştir. $P$. 
agglomerans'ın farklı suşlarının Erwinia amylovora türünün sebep olduğu hastalığa karşı etki gösteren antibiyotikler ürettiği saptanmıştır [10].

Bitki büyümesini teşvik için kullanılan mikroorganizmalardan olan Bacillus subtilis türü bitki patojenlerinin kontrolünde kullanılan birçok metabolit salgılar ve hücre parçalayıcı enzimler ve antibiyotik üretimi de gerçekleştirmektedir. Salgıladığı maddeler sayesinde fosfatı çözündürmek ve azotu fikse etmek gibi etkilerinin yanı sıra, bitkide strese bağlı oluşan hormonların üretimini engelleyerek bitkileri strese karşı daha dirençli hale getirebilmektedir [11].

Paenibacillus azotofixans suşu bitki büyümesini teşvik edici önemli türler arasında yer almaktadır. Nitrat varlığında azotu fikse edebildiği gözlemlenmiştir. $P$. azotofixans suşu buğday ve şeker kamışı bitkilerinin rizosfer bölgesinde baskın olarak bulunmaktadır [12]. Atmosferde gaz halinde bulunan azot $\left(\mathrm{N}_{2}\right)$ bitkiler tarafindan kullanılamaz. $\mathrm{N}_{2}$ fiksasyonu yapabilen türler sayesinde (Paenibacillus azotofixans, Azospirillum spp., Bacillus spp.) havadaki $\mathrm{N}_{2}$ gazı bitkilerin alabileceği forma dönüştürülür [13].

PGPR'ler bitkilerde fiziksel ve kimyasal olarak ortaya çıkan uyarılmış sistemik direnç (ISR) adı verilen değişikliklere sebep olabilmektedir. ISR'nin ortaya çıkmasıyla bitkiler patojenlere karşı daha dirençli hale gelmektedir [14]. Paenibacillus polymyxa suşunun metabolit üretimi yaptığı ve antibiyotik ürettiği bilinmektedir. Bu nedenle bitkilere verildiğinde bazı patojenleri baskıladığı bildirilmiştir [15]. $P$. polymyxa türü, salgıladığ 1 oksinler, giberellinler ve sitokininler sayesinde bitki büyümesini teşvik edebilmekte ve bitkiye direnç kazandırarak bitkileri patojenlere karşı dolaylı olarak koruyabilmektedir. $\mathrm{Bu}$ suşun aynı zamanda spor oluşturma kabiliyeti olduğu için, spor oluşturmayan bakterilere göre mikrobiyal ürün formülasyonunda daha avantajlı hale gelebilmektedir. P. Polymyxa'nın bazı suşlarının nitrojen fiksasyon kabiliyeti de yapılan çalışmalarda ortaya konulmuştur [16].

Bu çalışmada tarımda kullanılan 3 farklı sıvı mikrobiyal gübre uygulamasının Eisenia foetida türünün deri dokusunda oluşturduğu etkiler histolojik açıdan incelenmesi amaçlanmıştır.

\section{Materyal ve Metot}

Bu çalışmada Eisenia foetida 40 adet kullanıldı. Eisenia foetida 4 gruba ayrıldı. Plastik, üstü delinmiş kaplar içerisinde 30 gün boyunca çay posası, kahve telvesi, muz kabuğu ve yumurta kabuğu gibi besinlerle beslendi. Kontrol grubu hariç diğer 3 gruba üç farklı sıv1 mikrobiyal gübre uygulaması besin ortamına eklenerek gerçekleştirildi. Bütün gruplar aynı ortam şartlarında tutuldu. Çalışma grupları aşağıdaki gibi oluşturuldu.

Grup I (BM Megaflu): Günlük $2 \mathrm{~mL}$ sıvı mikrobiyal uygulanan Eisenia foetida'lar $(\mathrm{n}=10)$

Grup II (BM Coton Plus): Günlük 2 mL sıv1 mikrobiyal uygulanan Eisenia foetida'lar $(\mathrm{n}=10)$

Grup III (BM Root Pan): Günlük 2 mL sivı mikrobiyal uygulanan Eisenia foetida'lar $(\mathrm{n}=10)$

Grup IV (Kontrol): Mikrobiyal gübre uygulanmayan kontrol grubu $(\mathrm{n}=10)$

\subsection{Deneyde kullanılan sıvı mikrobiyal gübrelerin içeriği}


Deney esnasında Biomarket Tarımsal Biyoteknolojik Ürünler Tic. Ltd. Şti. şirketinin üretmekte olduğu 3 mikrobiyal gübre kullanıld1. Ürün içeriklerinde topraktan elde edilen rizosfer baterileri bulunmaktadır. Sırasıyla içerik aşağıdaki gibidir.

BM Megaflu: Bacillus megaterium, Pantoea agglomerans, Pseudomonas fluorescens BM Coton Plus: Bacillus subtilis, Paenibacillus azotofixans

BM Root Pan: Bacillus megaterium, Pantoea agglomerans, Paenibacillus polymyxa, Bacillus subtilis

\subsection{Dokuların alınması ve histolojik tekniklerin uygulanmast}

30 günlük denemenin ardından Eisenia foetida'ların vücut orta bölgelerinden alınan deri örnekleri \%10'luk formaldehit solusyonunda 48 saat süreyle fikse edildikten sonra rutin histolojik doku takibi uygulandı. Parafin bloklardan $5 \mu \mathrm{m}$ kalınlığında kesitler alınarak genel histolojik incelemeler için Hemotoksilen \& Eosin boyama yöntemi uyguland. Hazırlanan preparatlar araştırma mikroskobunda (Leica DM 500) incelenerek, filitre eşliğinde fotoğraflanmaları yapıldı.

\section{Bulgular}

\subsection{Kontrol grubuna ait bulgular}

Kontrol grubuna ait preparatların histolojik incelemesinde derinin epidermis ve dermis olmak üzere tabakalanma gösterdiği saptandı. Epidermisin derinin bazı kısımlarında tek katlı prizmatik epitelle bazı bölgelerde ise çok katlı kübik epitelle kaplı olduğu, bu epitel hücrelerinin arasında çok sayıda iri mukus hücrelerinin yerleşim gösterdiği gözlendi. Tek katlı prizmatik epitelin altında gevşek bağ dokusunun yer aldığı bu tabakayı da kollajen ipliklerce zengin sıkı bağ dokusunun takip ettiği belirlendi (Şekil 1, 2).

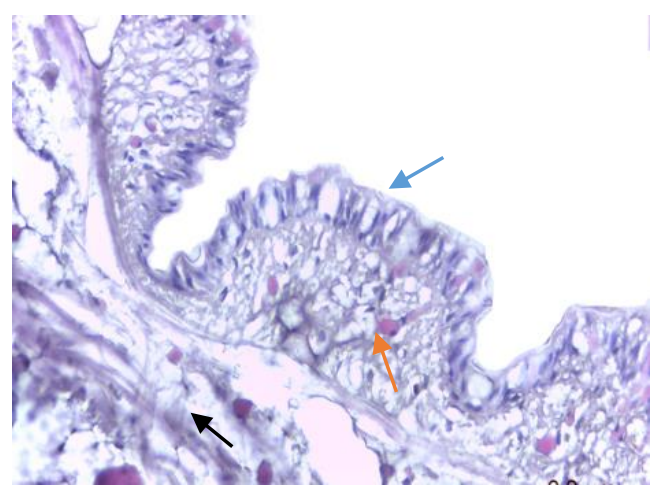

Şekil 1. Kontrol Grubu, Tek Katlı Prizmatik Epitel (mavi ok), Gevşek Bağ Dokusu (kırmızı ok), Sıkı Bağ Dokusu (siyah ok), H\&E, X 40

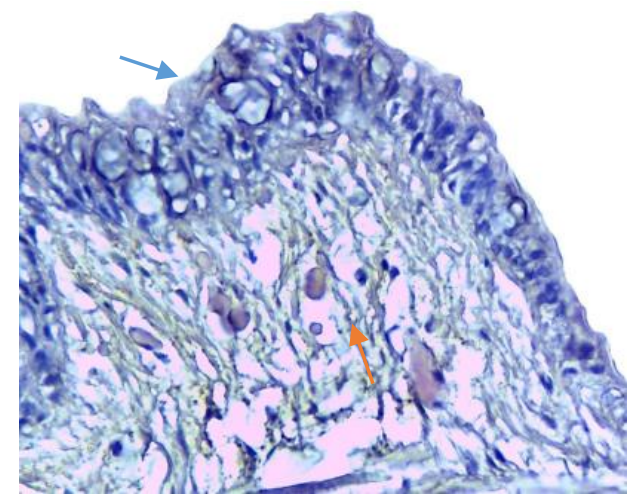


Şekil 2. Kontrol Grubu, Çok Katlı Kübik Epitel (mavi ok),

Gevşek Bağ Dokusu (kırmızı ok), H\&E, X 40

\subsection{Coton plus grubuna ait bulgular}

Coton plus sıv1 mikrobiyal gübre uygulanan gruba ait deri dokusunun histolojik incelemesinde epidermisin kontrol grubunda olduğu gibi çok katlı kübik epitelle kaplı olduğu bu hücrelerin arasında iri mukus hücrelerinin yer aldığı saptandı. Epitelin altında gevşek bağ dokusu ve sıkı bağ dokusunun devamlılık gösterdiği belirlendi (Şekil 3, 4).

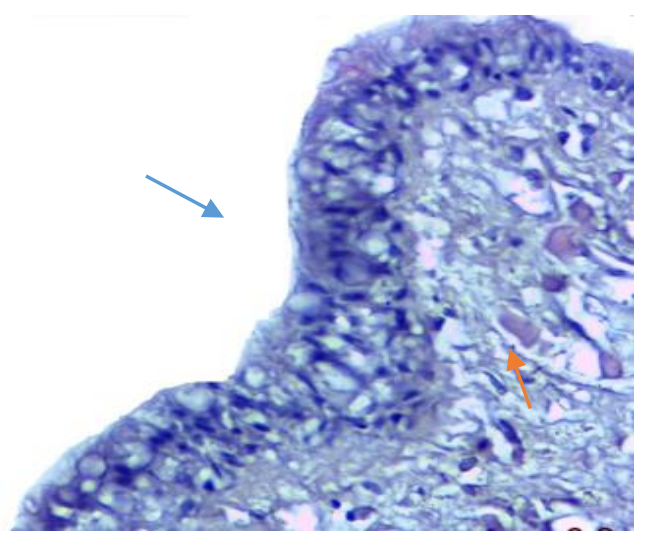

Şekil 3. Coton Plus Grubu, Çok Katlı Kübik Epitel (mavi ok), Gevşek Bağ Dokusu (kırmızı ok), H\&E, X 40

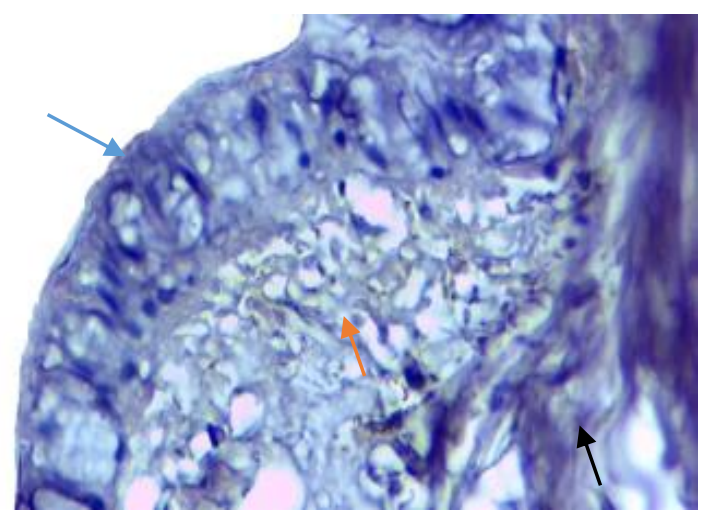

Şekil 4. Coton Plus Grubu, Çok Katlı Kübik Epitel (mavi ok), Gevşek Bağ Dokusu (kırmızı ok), Sıkı Bağ Dokusu (siyah ok), H\&E, X 40

\subsection{Megaflu grubuna ait bulgular}

Megaflu sıv1 mikrobiyal gübre uygulanan gruba ait deri dokusunun histolojik incelemesinde epidermisin lamina epitelyalisinin çok katlı kübik epitelle kaplı olduğu bu hücrelerin arasında iri mukus hücrelerinin yer aldığı saptandı. Epitelin altında gevşek bağ dokusu ve sıkı bağ dokusunun devamlılık gösterdiği belirlendi (Şekil 5, 6).

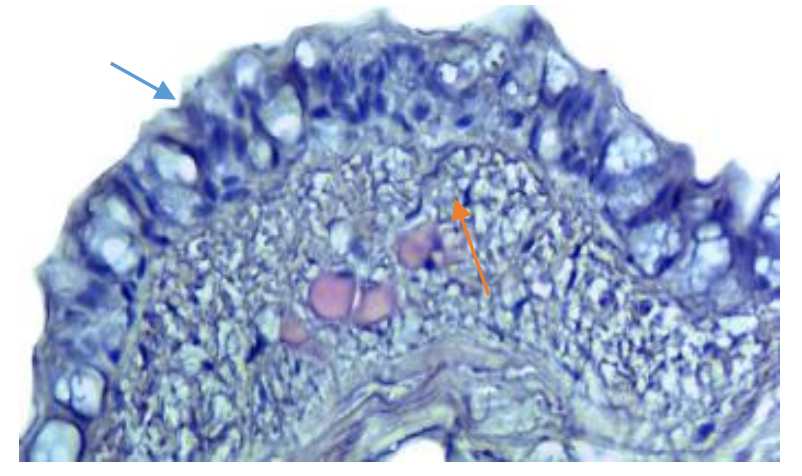


Şekil 5. Megaflu Grubu, Çok Katlı Kübik Epitel (mavi ok), Gevşek Bağ Dokusu (kırmızı ok), H\&E, X 40

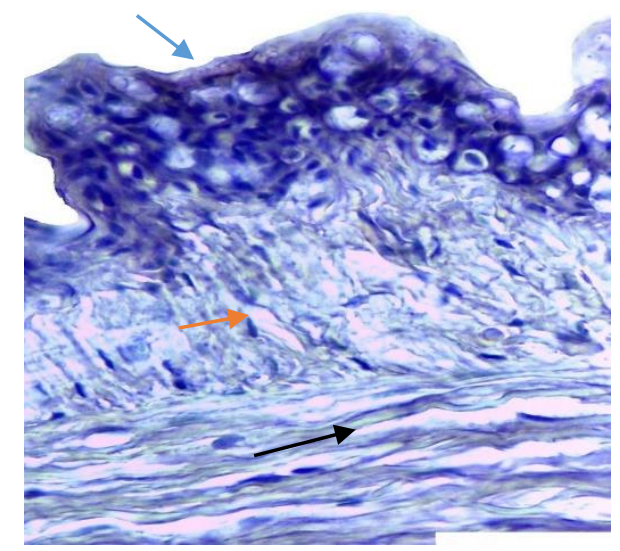

Şekil 6. Megaflu Plus Grubu, Çok Katlı Kübik Epitel (mavi ok), Gevş̧ek Bağ Dokusu (kırmızı ok), Sıkı Bağ Dokusu (kollajen iplikler), (siyah ok), H\&E, X 40

\subsection{Root pan grubuna ait bulgular}

Root pan siv1 mikrobiyal gübre uygulanan gruba ait deri dokusunun histolojik incelemesinde lamina epitelyalisin yer yer tek katlı prizmatik (Şekil 7) veya çok katlı kübik epitelle (Şekil 8) kaplı olduğu, bu hücrelerin arasında kontrol grubu ve diğer gruplara kıyasla şişkinliği daha az ve küçük çaplı mukus hücrelerinin yer aldığ1 saptandı. Epitelin altında gevşek bağ dokusu ve s1kı bağ dokusunun devamlılık gösterdiği belirlendi.

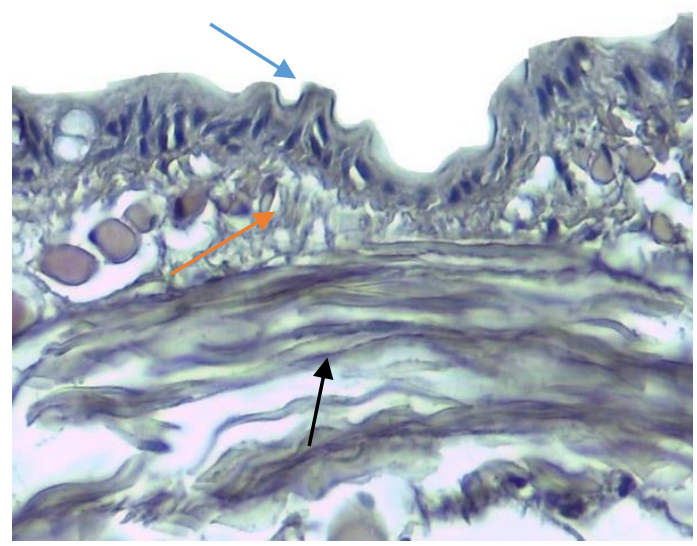

Şekil 7. Root Pan Grubu, Çok Katı Kübik Epitel (mavi ok), Gevşek Bağ Dokusu (kırmızı ok), Sıkı Bağ Dokusu H\&E, X 40

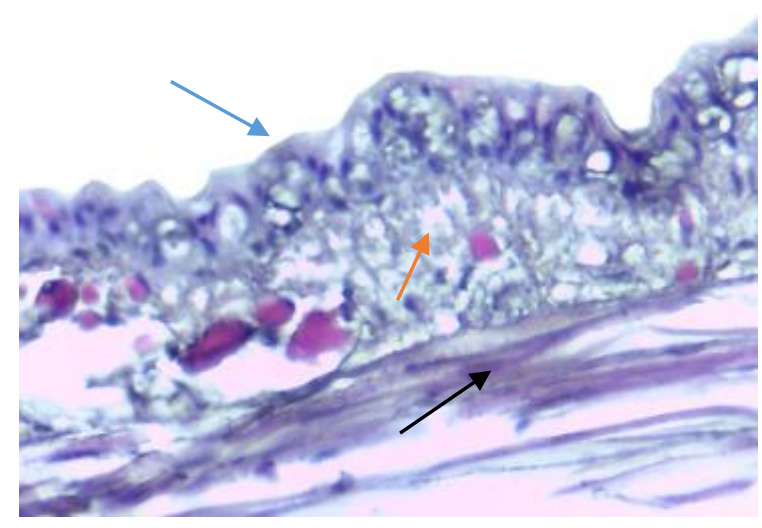


Şekil 8. Root Pan Grubu, Çok Katlı Kübik Epitel (mavi ok), Gevşek Bağ Dokusu (kırmızı ok), Sikı Bă̆ Dokusu, H\&E, X 40

\section{Sonuç ve Yorum}

Solucanlar toprak ekosisteminin en büyük bölümünü oluşturmaktadır. Sağlıklı ve kaliteli bir toprağın belirteci olarak kabul edilmektedirler. Toprakta sağladığı döngüler sebebiyle bir nevi ekoloji mühendisleri olarak anılmaktadırlar. Kirlenmiş topraklardaki ağır metal birikimi veya toksisitenin ölçülmesinde biyogözlemci olarak en ideal canlılardır. Toprak solucanlarının kirlenmiş arazilerde veya atık çamurlardaki $\mathrm{Cr}, \mathrm{Cu}$, $\mathrm{Pb}$ ve $\mathrm{Zn}$ gibi metallerin oranlarını 60 dakika United States Environmental Protection Agency (USEPA) tarafından belirlenmiş olan sınırların altında indirdiği gözlemlenmiştir. Yapılan bir çalışmada, Eisenia foetida'nın topraktaki birikmiş $\mathrm{Pb}$ içeriğini bir miktar azalttığı saptanmıştır [17].

Tarımda kullanılan pestisit adı altındaki kimyasalların yaygın ve dünya genelinde kullanımı toprak kirliliğine neden olmuştur ve bu durum gün geçtikçe artan bir endişe uyandırmaktadır. Pestisitlerin toprağa verildikten sonra nelere sebep olduğunun bilinmesi zorunlu hale gelmektedir. Kullanılan kimyasallar toprak organizmalarının sağlığını etkilemektedir. Toprak organizmaları, topraktaki besin içeriğinin düzenlemesine yardımcı olmaktadır. Toprak solucanları; toprağa verilen çöp, atık vs. gibi maddeleri besin olarak kullanarak organik maddeye dönüştürür [18]. Gümüş elementi endüstriyel alanların bazılarına antimikrobiyal ajan olarak kullanılabilmektedir. Çeşitli alanlarda kullanılan Ag nanoparçacıları (AgNP) çevreye kirletici etki göstermektedir. Yine bir diğer kirletici madde ise Co nanoparçacıları (CoNP)'dır. Bu maddeler topraklarda birikim doğrultusunda toksik etkiye yol açabilmektedir. Toprak mikro ve makroorganizmalarına doğrudan toksik etki yapabilmektedir. Bu nedenle topraktaki aktivitelerin azalmasına neden olmaktadır. Solucanların topraktaki aktiviteleri solucanların bağırsağında toprağa göre daha fazla mikrobiyal populasyon barındırmalarına sebep olur. Solucanlar yutulmuş mikroorganizmaları sindirim kanallarında değiştirerek dışkılarından organik atıkla beraber vermikompost olarak toprağa geri verirler. Ag ve Co nanopartikülleriyle beslenen toprak solucanlarının bağırsaklarındaki değişimler araştırılmıştır. Çünkü solucanlar da belli başli kirleticilerden direkt olarak etkilenebilmektedir. Depürasyon döneminden sonra Ag ve Co'ların solucanların bünyesinde kalabileceği ve böylece sağlıklarına zararlı etki yapabileceği öne sürülmüş ve toprak solucanlarının yapısındaki biyokimyasal değişimle araştırılmıştır [19]. Bu bilgilerden yola çıkarak yaptığımız çalışmada toprağa verilen ürünlerin toprak canlılarında bir hasara yol açıp açmadığının gözlemlemek istedik. Bu çalışmada kullanılan organik ve çevre dostu olarak satılan mikrobiyal gübrelerin Eisenia foetida'ya uygulanması sonucunda deri dokusunda histolojik açıdan herhangi bir olumsuz etki oluşturmadığı gözlemlendi.

Günümüzde çevre kirliliğine olan duyarlılık artmıştır. Ağır metal kirletici olarak kurşunun insan sağlığ 1 açısından birçok toksik etkisi bulunmaktadır. Kurşunun ağır metal toksisitesini ölçmek ve sinırlandırmak için solucanlar kullanılmıştır. Orta bağırsaktan alınan kesitte yüksek kurşun konsantrasyonu ile morfolojinin değiștiği ve bağırsak zarının yırtıldığı, bazı hücresel deformasyonlar ve nekroze olmuş alanların oluştuğu bildirilmiştir [17]. Çalışmamızda mikrobiyal gübre ile muamele edilmiş solucanların histolojik incelemelerinde deri dokusunda bir hasar oluşturmadığı saptandı. 
Tütün, soya fasulyesi, sorgum, mısır ve pamuk gibi bitkilerde örümcek akarı, emici ve çiğneyici böceklerin kontrolünde geniş spektrumlu orgonafosfat grubu monokrotofos adında bir pestisit kullanılmaktadır. Lampito mauritii türü solucan tarım arazilerinde çokça karşılaşılan türlerdendir. Topraktaki kirliliği belirlemek amacıyla Hindistan'daki çalışmalarda belirleyici tür olarak seçilmiştir. Solucanlar topraklarda kirleticilere ve ağır metallere oldukça maruz kalmaktadırlar. Histolojik yöntemler sayesinde Lampito mauritii doku düzeyindeki hasarlar ölçülmüştür. Yapılan çalışma sonucunda makrotofosun mikrobiyal populasyonu değişikliğe uğrattığ 1 ve histopatolojik değişikliklere sebep olduğu bildirilmiştir [18]. Bu çalışmadan farklı olarak çalışmamızda histopatolojik etki gözlenmemiştir.

Endüstride kullanılan tasarlanmış nanomalzemelerle yüzeyler kaplanarak daha da aktif hale getirilebilirler. Fakat kaplamaların ekolojik olarak ne denli toksik olduğu ve topraklarda birikmeye ya da yaşlanmaya sebep olup olmadığı bilinmemektedir. $\mathrm{CuO}$ endüstriyel nanomalzemeler (ENM) farklı yüzey maddeleri ile kaplandıktan sonra toksik olup olmadığının incelenmesi için biyobelirteç olarak Eisenia foetida kullanılmıştır. $\mathrm{CuO}$-çekirdek, $\mathrm{CuO}-\mathrm{ENM}, \mathrm{CuO}-\mathrm{COOH}$ olarak üç farklı ajanla muamele yapılmıştır. $\mathrm{CuO}$ ile muamele edilen solucanlarda deri dokusunda goblet hücrelerinde çok az miktarda gelişememe ve hücre azlığının gözlendiği bildirilmiştir [20]. Bu çalışmada ise deri dokusunun histolojik incelemelerinde hasar tespit edilmemiştir.

Toprak solucanlarına karşı yüksek derecede toksik olduğu bilinmekte olan bileşik benomil, fungisit olarak tarım arazilerinde kullanılmaktadır. Benomilin sitofor (omurgasızlarda sitoplazmanın artık kütlesi) yapısında mikroskobik düzeyde hasara yol açtığı, benomile nazaran metil 2-gbenzamidil karbamatın daha ciddi ve kalıcı hasarlara sebep olduğu bildirilmiştir [21]. Yapılan çalışma gösteriyor ki, tarımda zararlı kontrolü için kullanılan kimyasal maddeler topraktaki canlıların sağlıklarını olumsuz yönde etkilemektedir. Bizim çalışmamızda ise uygulanan sıvı mikrobiyal gübrelerin deri dokusunda histolojik açıdan incelemelerde hasar oluşturmadığı tespit edildi.

Tarım arazilerinde, yetiştirilen mahsulü zararlılardan korumak için fazlaca pestisit ve herbisit kullanılmaktadır. Kullanılan bu kimyasal kaynaklı ürünler topraklarda birikmeye neden olmaktadır. Örneğin 2,4-diklorofenoksi asetik asit düşük maliyetli kolay temin edilebilir oldukça etkili bir herbisittir. Fakat memelilerde yan etki olarak; nörolojik işlev bozukluğu, akciğer ödemi, hepatit ve çeşitli böbrek hastalıklarına sebep olabilmektedir. Yabanc1 ot mücadelesinde yaygın olarak kullanılan bu herbisitin toprak solucanı Eutyphoeus waltoni üzerinde göstermiş olduğu toksik etkiler araştırılmış ve etkinin zamana ve doza bağlı olarak değiştiği, yüksek dozlarda 2,4-diklorofenoksi asetik asit herbisitinin Eutyphoeus waltoni türü solucanında toksik etki oluşturduğu bildirilmiştir [22]. Bu çalışmada ise histolojik açıdan solucanların deri dokusunda herhangi bir olumsuzluğa rastlanmamış olup kullanılan mikrobiyal gübrelerin deri dokusunda toksik etki oluşturmadığı tespit edilmiştir.

Solucanların vücut yüzeylerinde toprakta bulunan zararlı kimyasalları ve ağır metalleri ayırt etmesini sağlayacak seçici reseptörleri bulunur. $\mathrm{Bu}$ nedenle pestisitlerin hedef bölgelerden dışarıya kayıp kaymadığını anlamak için en iyi belirteçler solucanlardır. Toksisite testlerinde en uygun modeller bu nedenle solucanlar olmaktadir. Yapilan denemeler sonucunda kullanılan böcek ilaçlarının sadece hedef bölgeyi değil aynı zamanda çevrede bulunan diğer tarım arazilerini de etkilediği, solucanlar üzerinde toksik etki yarattığı bildirilmiştir [23]. Fakat bizim çalışmamızda deri dokusunda hasara rastlanmamıştır. 
Toprak solucanlarına akut toksisite gösteren profenofos (PFF)'un Eisenia foetida türü solucana toksik etkisini değerlendirmek amacıyla yapılan çalışmada Eisenia foetida'ya PFF inhibisyonu uygulanmıştır. Etkinin zamana ve doza bağlı olarak değiştiği, PFF verilen tüm solucanlarda halsizlik olduğu, maruz kalma sürelerinin ve dozun artışına göre vücutlarının arka kısımlarında kanlı lezyonlarla sonuçlanan sölomik sıv1 ekstrüzyonu oluştuğu bildirilmiştir [24]. $\mathrm{Bu}$ çalışmadan farklı olarak bizim çalışmamızda bu bulgulara rastlanmamıştır.

Dünya genelinde en yaygın kullanılan patlayıcı olan TNT (Trinitrotoluen)'nin öncüsü olan DNT (Dinitrotoluen) aynı zamanda endüstriyel poliüretan köpük üretiminde kullanılan diizosiyanatın da öncüsüdür. Bu bileşikler oldukça toksik olmasına rağmen DNT tarım arazilerinde ilaçlama için kullanılmıştır. ABD Çevre Koruma Ajansınca çevre kirleticiler sınıfına girmiş olan DNT belli bir dönem tarım arazilerinde çokça kullanılmıştır. DNT normal çevre koşullarında bile çok kolay şekilde indirgenebilen bir maddedir. Organik madde parçalayıcısı olarak bilinen Eisenia foetida türü solucanlar ise bağırsaklarında kimyasal parçalayıcı mikroorganizmalar bulundurmaktadır [25]. Bu nedenle topraklardaki solucanların varlığı sayesinde topraklara verilmiş kimyasalların dönüşümü ve degradasyonu kısmi olarak sağlanabilir. Kirleticiler topraklardan solucanlar tarafından arındırılabilir. Bu sebeplerden dolayı topraklardaki solucanların varlığı ve sağlığı, çevre ekolojisi için oldukça önemlidir.

Sonuç olarak çalışmamızda, tarımda kimyasal gübre, pestisit, herbisit ve böcek ilaçları kullanımını azaltmak amacıyla üretimi yapılan üç farklı mikrobiyal gübrenin toprak solucanlarına karşı etkileri histolojik açıdan araştırıldı. Mikrobiyal gübre uygulamasının toprak solucanı Eisenia foetida'nın deri dokusundaki etkisinin 1şık mikroskobik açıdan değerlendirilmesinde histopatolojik herhangi bir olumsuzluk gözlenmemiştir. Çalışmamız biyokimyasal ve moleküler çalışmalarla da desteklenip aynı sonuçlar elde edildiği takdirde, mikrobiyal gübre kullanımının toprakta yoğun olarak bulunan ve toksisite belirteci olarak kullanılan toprak solucanlarına zarar vermediği sonucuna ulaşabiliriz. Bu çalışmada toprak solcanının sadece deri dokusu histolojik açıdan incelenmiş olup, diğer dokularında da sıvı mikrobiyal gübre kullanımının etkilerinin ayrıntılı olarak incelenmesi çalışmamıza katkı sağlayacaktır.

\section{Destek ve Teşekkür Beyanı}

Çalışmamızın solucanlara sıvı gübre verilme aşaması Şeyma Rukiye Yayla, deneme sonrası dokuların alınması ve histolojik yöntemlerin uygulanması Nurgül Şenol ve Şeyma Rukiye Yayla, dokularda mikroskobik incelemeler ve değerlendirmelerin yapılması Nurgül Şenol tarafindan gerçekleştirilmiştir. Makalenin yazım işlemlerinde her iki yazar eşit oranda katkı sağlamıştır. Çalışmamızda deney esnasında Biomarket Tarımsal Biyoteknolojik Ürünler Tic. Ltd. Şti. şirketinin üretmekte olduğu 3 farklı sıv1 mikrobiyal gübre kullanılmış olup verdikleri katkıdan dolayı teşekkür ederiz.

\section{Çatışma Beyanı}

Çalışmamızda yazarlar arasında ya da çalışmaya sıvı gübre temini ile destek sağlayan Biomarket Tarımsal Biyoteknolojik Ürünler Tic. Ltd. Şti. şirketi ile çatışma bulunmamaktadır.

\section{Kaynakça}

[1] E. Kılavuz, İ. Erdem, "Dünyada tarım 4.0 uygulamaları ve Türk tarımının dönüşümü," Social Sci., 14(4), 133-157, 2019.

[2] H. Ünlü, H. Padem, "Organik domates yetiştiriciliğinde çiftlik gübresi, mikrobiyal gübre ve bitki aktivatörü kullanımının yaprakların makro element içeriği üzerine etkisi," Süleyman Demirel Üni. Ziraat Fak. Derg., 5, 63-73, 2010. 
[3] N. Okur, H. H. Kayıkçığlu, G. Tunç, ve Y. Tüzel, "Organik tarımda kullanılan bazı organik gübrelerin topraktaki mikrobiyal aktivite üzerine etkisi,” Ege Üniv. Ziraat Fak. Derg., 44 (2), 65-80, 2007.

[4] S. Kiracı, E. Gönülal, ve H. Padem, "Mikrobiyal gübre ve bitki aktivatörü uygulamalarının organik havuç yetiştiriciliğinde kalite parametreleri üzerine etkisi,” Süleyman Demirel Üni. Ziraat Fak. Derg., 8, 36-43, 2013.

[5] K. C. Odoh, "Plant growth promoting rhizobacteria (PGPR): a bioprotectant bioinoculant for sustainable agrobiology," Int. J. Adv. Res. Biol. Sci., 4, 123-142, 2017.

[6] D. Bhardwaj, M. W. Ansari, R. K. Sahoo, and N. Tuteja, "Biofertilizers function as key player in sustainable agriculture by improving soil fertility, plant tolerance and crop productivity," Microbial Cell Factories, 13(66), 1-10, 2014.

[7] R. Mendes, P. Garbeva, J.M. Raaijmakers F., "The rhizosphere microbiome: significance of plant beneficial, plant pathogenic, and human pathogenic microorganisms," FEMS Microbiology Reviews, 37(5), 634-663, 2013.

[8] M. Rolewicz, P. Rusek, and K. Borowik, "Obtaining of granular fertilizers based on ashes from combustion of waste residues and ground bones using phosphorous solubilization by bacteria Bacillus megaterium," J. Environ. Manag., 216(15), 128-132, 2018.

[9] S. Bolandnazar, A. Sharghi, H. Naghdi Badhi A. Mehrafarin, M.R. Sarikhani, "The impact of Sinorhizobium meliloti and Pseudomonas fluorescens on growth, seed yield and biochemical product of fenugreek under water deficitstress," Adv. Hort. Sci., 32(1), 19-26, 2018.

[10] S. R. Giddens, G. J. Houliston, and H. K. Mahanty, "The influence of antibiotic production and preemptive colonization on the population dynamics of Pantoea agglomerans (Erwinia herbicola) Eh1087 and Erwinia amylovora in planta," Environ. Microbiol., 5, 1016-1021, 2003.

[11] A. Hashem, B. Tabussum, and E. F. Abd-Allah, "Bacillus subtilis: a plant growth promoting rhizobacterium that also impacts biotic stress," Saudi J. Biol. Sci., 26, 1291-1297, 2019.

[12] M. N. Pires, and L. Seldin, "Evaluation of Biolog system for identification of strains of Paenibacillus azotofixans," Biotech., 71, 195-200, 1997.

[13] L. Seldin, A. S. Rosado, D. W. D. Cruz, A. Nobrega, J. D. V. Elsas, and E. Paiva, "Comparison of Paenibacillus azotofixans strains isolated from rhizoplane, rhizosphere, and non-root-associated soil from maize planted in two different brazilian soils," Appl. Environ. Microbiol., 64, 3860-3868, 1998.

[14] J. Yang, W. J. Kloepper, and C. M. Ryu, "Rhizosphere bacteria help plants tolerate abiotic stress," Trends in Plant Sci., 14(1), 1-4, 2009.

[15] S. Timmusk, E. Wagner, and H. Gerhart, "The plant-growth-promoting rhizobacterium Paenibacillus polymyxa induces changes in Arabidopsis thaliana gene expression: a possible connection between biotic and abiotic stress responses," The American Phytopathological Society, 11, 951-959, 1999.

[16] S. Lal, S. Tabacchioni, "Ecology and biotechnological potential of Paenibacillus polymyxa: a minireview," Indian J. Microbiol., 49(1), 2-10, 2009.

[17] A. Das, and J. W. Osborne, "Enhanced bioremoval of lead by earthworm-Lumbricus terrestris cocultivated with bacteria-Klebsiella variicola," J. Photoch. Photobio. B, 175, 65-72, 2017.

[18] K. Vaithiyanathasamy, A. Ramachandran, S. A. Naiyf, K. Shine, M. K. Jamal, N. A. Taghreed, and G. Marimuthu, "Impact of pesticide monocrotophos on microbial populations and histology of intestine in the Indian earthworm Lampito mauritii (Kinberg)," Microb. Pathogen., 139, 103893, 17, 2020.

[19] L.V. Antisari, S. Carbone, A. Gatti, S. Ferrando, M. Nacucchi, F.D. Pascalis, C. Gambardella, L. Badalucco, and V.A. Laudicina, "Effect of cobalt and silver nanoparticles and ions on Lumbricus rubellus health and on microbial community of earthworm faeces and soil," Appl. Soil Ecol., 108, 62-71, 2016.

[20] K. Tatsi, B.J. Shaw, Hutchinson, T.H., Handy, "Copper accumulation and toxicity in earthworms exposed to $\mathrm{CuO}$ nanomaterials: effects of particle coating and soil ageing," Ecotoxicol. Environ. Safety, 166, 462-473, 2018.

[21] J. Sorour, and O.L.Larink, "Toxic effects of benomly on the ultrastructure during spermatogenesis of the earthworm Eisenia foetida," Ecotoxicol. Environ. Safety, 50, 180-188, 2001.

[22] V. Singh, and K. Singh, "Toxic effect of herbicide 2,4-d on the earthworm Eutyphoeus waltoni Michaelsen," Environ. Process., 2, 251-260, 2015.

[23] S.A. Reinecke, and A.J. Reinecke, "The impact of organophosphate pesticides in orchards on earthworms in the Western Cape, South Africa," Ecotoxicol. Environ. Safety, 66, 244-251, 2007.

[24] N.C. Reddy, and J.V. Rao "Biological response of earthworm, Eisenia foetida (Savigny) to an organophosrous pesticide, profenofos," Ecotoxicol. Environ. Safety, 71, 574-582, 2008. 
[25] K.H. Shin, Y. Lim, J.H. Ahn, J. Khil, C.J. Cha, and H.G. Hur, "Anaerobic biotransformation of dinitrotoluene isomers by Lactococcus lactis subsp. lactis strain 27 isolated from earthworm intestine," Chemosphere, 6, 30-39, 2005. 